
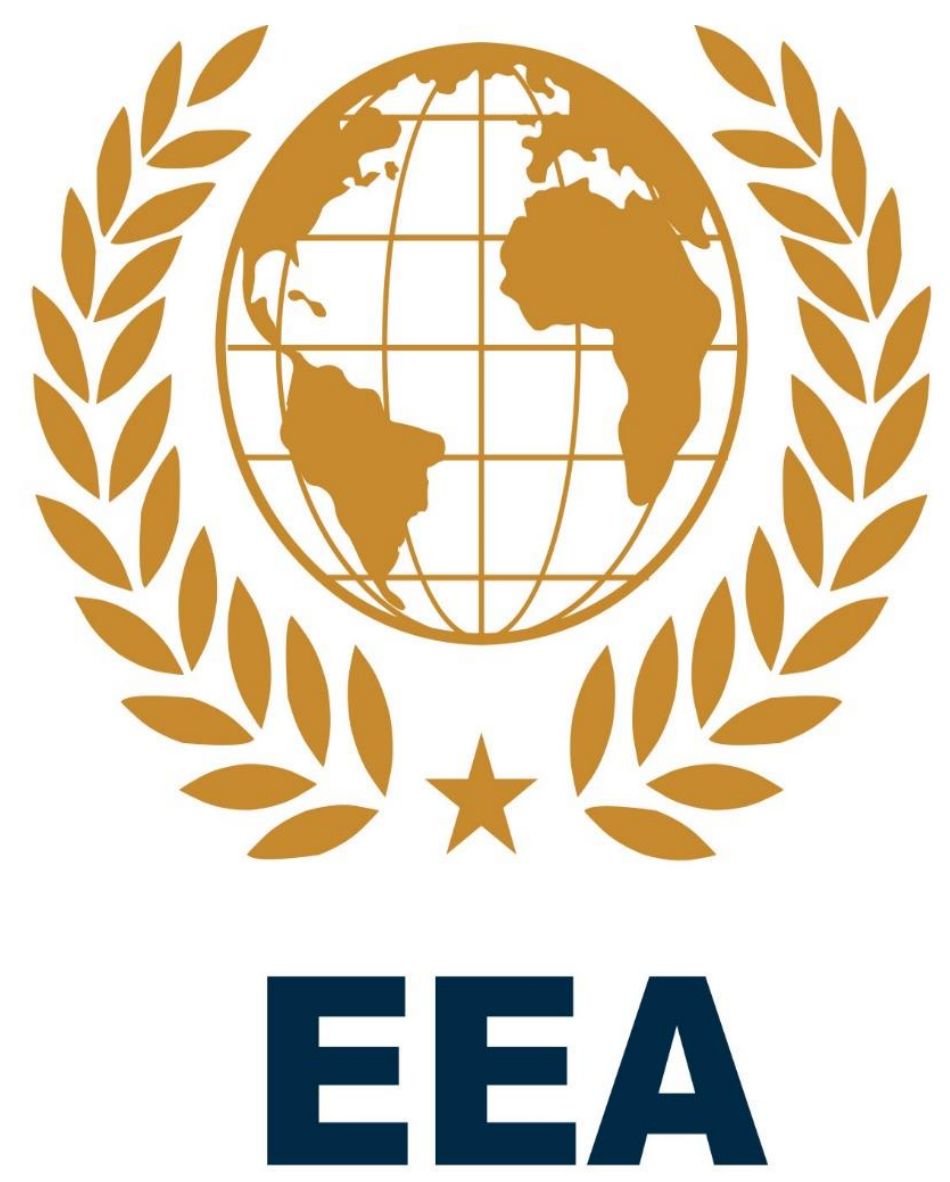

East European Affairs

\author{
1 \\ 2020
}


DOI: $10.47669 / E E A-1-2020$

\title{
Failed Europeanization? Belarus and Armenia Between Russia and the EU
}

\section{Aram TERZYAN*}

\begin{abstract}
This paper explores the core challenges and opportunities of the Europeanization processes taking place in Belarus and Armenia. It argues that despite the constraining effects of "competing governance provider" Russia, the interests, perceptions, and preferences of the domestic elites are critical to the implementation of the EU policies in Belarus and Armenia. Thus, it offers a more dynamic structure-agency interplay approach to account for the dynamics of Europeanization in the EU-Russia contested neighbourhood. The article enquires into integration without membership dynamics between the EU and Eastern neighbours in the light of the Russian-dominated Eurasian integration.
\end{abstract}

Keywords: Europeanization; Belarus; Armenia; Eurasian integration; Russia; CEPA.

\section{Introduction}

Of all the Eastern Partnership (EaP) countries, Armenia and Belarus are by far the most vulnerable to Russian influence. Unlike the other Eastern partners, Belarus and Armenia are bound by their membership in the Russia-led Eurasian Economic Union (EAEU), when seeking closer partnership with the EU.

Clearly, the mounting assertiveness of "competing governance provider" Russia towards the EU's greater engagement with Belarus and Armenia has posed significant challenges to their Europeanization. Ademmer (2015) has drawn on the original work on interdependence in the discipline of International Relations to identify specific conditions under which Russia exerts either supportive or constraining effects on EU policy transfer. The comparative case study on energy policy change in Georgia and Armenia, shows that the distinction of different forms of interdependence and their interplay with Russia's quid pro quo bargaining, as well as with political preferences of domestic incumbents, are critical to make sense of Russia's seemingly Janus-faced role in the neighbourhood (Ademmer, 2015).

Overall, despite the constraining effects of "competing governance provider" Russia, domestic actors have considerable agency to implement the EU policies. Despite the

\footnotetext{
* Aram Terzyan, PhD is research director of Los Angeles-based Center for East European and Russian Studies of Eurasia Institutes. Email: a.terzyan@eurasiainstitutes.org .
} 
increasing external competition over the post-Soviet space, domestic actors remain the key agents to account for the pattern of change in the contested neighbourhood" (Ademmer, Delcour and Wolczuk, 2016). Therefore, this study offers a more dynamic structure-agency interplay approach to account for the dynamics of Europeanization in the EU-Russia contested neighbourhood.

Notably, the EU-Armenia CEPA has been regarded as an edited version of the Association Agreement, which gives a new impetus to the partnership following the setbacks, endured Armenia's perplexing U-turn (Kostanyan and Giragosian, 2017). Even though the new agreement includes a considerable amount of the EU acquis in legally binding provisions across a range of sectoral areas of cooperation, although the effectiveness of CEPA's essential degree of conditionality remains in question (Kostanyan and Giragosian, 2017). While the Europeanization literature emphasizes the transformative and democratizing power of the EU (Schimmelfennig and Sedelmeier, 2004; Vachudova, 2005; Grabbe, 2006), its conditionality (reforms in return for funds and membership) is deemed pivotal to EU policy transfer. Thus, there is a broad scholarly consensus that the EU has been able to influence domestic change through the policy of conditionality (Rakovita, 2011). Moreover, the "external incentive model (Schimmelfenning and Sedelmeier 2004)" has been more germane to accounting for the EU's ability to influence domestic change and rule adoption than models of socialization (Racovita, 2011).

A question remains as to whether the EU's conditionality can prove effective in Armenia and Belarus given the two countries' membership in the Russia-led EAEU and limited openness to the "Market Power Europe" (Damro, 2010).

This study explores the integration without membership dynamics between the EU and its Eastern neighbours. It explores the dynamics of the Europeanization processes in Belarus and Armenia amid constraining conditions provided by "competing governance provider" Russia. It examines the influence of domestic political elites and local powerful groups over shaping, changing or even obstructing the process of the countries' approximation towards Europe.

This article is an in-depth case analysis that uses policy analysis and process tracing to examine the core dynamics of the Europeanization processes in Belarus and Armenia. The case study of Belarus and Armenia serves as a plausibility probe that illustrates the integration without membership dynamics between the EU and its Eastern neighbours. The study builds 
its empirical argumentation by analysing a broad variety of sources, including the newspaper articles, observations from political speeches, official documents, and interviews.

\section{EU External Governance and Eastern Neighbours}

The main rationale behind the EU's European Neighbourhood Policy (ENP) and Eastern Partnership (EaP) has been to bring the countries situated in its strategic vicinity "closer to the European Union in a number of priority fields", thus creating a "ring of friends" with whom to share "everything but institutions" (Prodi, 2002).

Yet, the EU has was confronted with the proverbial 'expectation-reality' gaps in its Eastern neighbourhood amid low responsiveness from the part of its neighbours towards some of its demands for reform, on the one side, and a mounting Russian resistance to the policies of Europeanization and region-building, on the other side.

When introducing the ENP review in November 2015 the EU Commissioner for European Neighbourhood Policy and Enlargement Negotiations, Johannes Hahn, aptly noted that the EU's neighbourhood was degenerating from a ring of friends to "a ring of fire or volcano" (Hahn, 2015).

Essentially, one of the biggest challenges facing the EU is how to encourage its neighbours to comply with its policies and thus translate its vision of a prosperous, secure and stable neighbourhood into reality. This provokes an enquiry into the modes and prerequisites for the EU external governance, i.e. effective application of the EU rules beyond its borders amid complex interactions with "competing governance provider" Russia. According to the external governance approach - a major analytical perspective on nonaccession Europeanization - the effectiveness of rule transfer is chiefly explained by existing EU institutions, which 'provide the template for the externalisation of EU policies, rules and modes of governance' (Lavenex and Schimmelfennig, 2009, p. 802).

Therefore, its effectiveness considerably depends on its hierarchical mode and the ability of the EU institutions to monitor and enforce the agreements and ensure rule compliance. In contrast to the institutional approach, the power-based explanation suggests that external governance is determined by the EU's power and its interdependence with regard to third countries as well as competing 'governance providers' in its neighbourhood mainly the United States and Russia (Lavenex and Schimmelfennig, 2013, pp.14-15). In this regard, the modes of external governance correspond to external structures of power and interdependence rather than EU internal institutional structures. The hierarchical mode of governance requires third countries to be both strongly dependent on the EU and more 
strongly dependent on the EU than on alternative governance providers (Lavenex and Schimmelfennig, 2009, pp. 803-804). Without such sheer and asymmetric interdependence in its favour, the EU will be incapable of imposing hierarchical governance upon third countries.

Some observers find the above- mentioned approaches more applicable to partner countries, rather than the domestic structure explanation, referring to the compatibility of EU rules with partner countries' traditions, institutions and practices (Delcour and Wolczuk, 2015, p. 493). In other words, domestic structure explanation assumes that the effectiveness of external governance is contingent upon its compatibility with domestic institutions, rather than upon international institutions and power (Lavenex and Schimmelfennig, 2013, p. 15).

Arguably, according to all three accounts identified above, Armenia and Belarus should not be responding to EU demands for reform

Firstly, both Armenia and Belarus have not pursued EU membership and has limited their aspirations to the deep and comprehensive partnership option. Meanwhile, the lack of a clear membership perspective would inevitably hinder the effective transfer of the EU rules in in the two countries.

Secondly, the authoritarian rulers both in Belarus and Armenia would not have strong incentives in the Europeanization of the two countries' political and economic systems, given the foreseeable challenges for their rules.

Last but not least, the two countries' huge political and economic dependence on "competing governance provider" Russia, vividly manifested their membership in the Russia-led Collective Security Treaty Organisation (CSTO) and Eurasian Economic Union, would inevitably interfere with consistent compliance with the EU policies. Therefore, the question of whether and to what extent the two countries' Eurasian integration is agreeable with the EU approximation comes down to determining the preferences, perceptions, and interests of the domestic actors, as well as to the Russian impact on the European rules and norms diffusion inside its "sphere of influence."

\section{The EU vs. the "competing governance provider": Belarus and Armenia between constrained $\mathrm{EU}$ and affirmative Russia}

While the institutionalist approach would find the EU institutions indispensable to the effectiveness of the EU external governance, the power-based explanation would posit that “external governance is determined by the EU's power and its interdependence with regard 
to third countries as well as "competing governance providers" in its neighbourhood - mainly the US and Russia (Lavenex and Schimmelfennig, 2013, pp.14-15).

This comes down to the challenges of Europeanization in the EU-Russia contested neighbourhood, where the EU's "transformative power" and region-building policies are faced with Russian "authoritarian resistance" and "region-spoiling" measures (Ambrosio, 2016; Delcour and Wolczuk, 2017).

The ongoing crisis in Ukraine is indicative of the volatile new phase of the EU-Russia relations in their common neighbourhood, fraught with the Kremlin's unshakable determination to obstruct further Europeanization in the sphere of its "privileged interests." Russia's mounting assertiveness has been manifested in its unrelenting efforts at promoting its preferred vision of order beyond its borders under the form of the Eurasian Economic (Customs) Union launched in 2010. As a long term project aimed at regaining the Russian control over post-Soviet space, the Eurasian Union was bound to collide with the Eastern Partnership as the European and Russian visions for the 'shared' Eastern neighbourhood remain self-centred and exclusionary (Korosteleva, 2016).

In effect, the EU and Russia find themselves locked in parallel rather than complementary relations with the 'shared' region, each attempting to institutionalise its own political order (Korosteleva, 2016). Delcour and Wolzuk (2017) argue that while the EU promotes soft and indirect region-building, Russia pursues regional integration as well as region-spoiling with a view to securing regional hegemony (Delcour and Wolczuk, 2017).

When viewed from Brussels, the Eastern Partnership would step up EU's “constructive engagement" with its neighbourhood, with the view to transforming it into an area of democracy, peace, and prosperity (Haukkala, 2018, p. 84). Meanwhile, the Kremlin would treat the EaP as European intrusion in its sphere of influence, as for Russia, converging with the acquis means a shift away from what ties EaP countries have with Moscow (Delcour and Kostanyan, 2014, p. 3).

It is for these reasons that Putin threw his back behind promoting the Eurasian Union, most vividly by forcing Armenia to join it. A glance at Armenia's perplexing U-turn on the eve of signing the Association Agreement are indicative of the depth and scope of the coercive measures that Russia took to prevent the Association Agreements from taking effect. While post-revolution Ukraine's President Piotr Poroshenko promptly signed the Association Agreement, the Armenian Prime Minister, Nikol Pashinyan was quick to confirm Armenia's commitment to Eurasian integration (Terzyan, 2019a, p. 27). He denied the possibility of 
foreign policy U-turns while stressing the necessity of further rapprochement with Armenia's ‘indispensable ally’ Russia (Pashinyan, 2018a).

Overall, there is a broad consensus among the representatives of the Armenian political elite that the acute threats posed to Armenia by Azerbaijan and Turkey prompt to put heavy reliance on Russia. Thus, despite some resentment that Russian policy may generate, Armenia has to abstain from 'provoking' Russia'. Otherwise, the latter would 'hit where it hurts', by arming Azerbaijan, increasing gas prices or even mistreating the Armenian community in Russia. It follows that Armenia has no choice but to abide by the rules determined by the Kremlin (Terzyan, 2017, p. 192). That said, irrespective of the domestic change, Armenia is faced with the path dependency and there is no magic bullet to reverse the country's immense dependence on Russia and its absorption into the Russia-led Eurasian Union.

The development of EU-Belarus partnership is inherently linked to the bilateral relationship between Belarus and Russia. Under the Lukashenko's regime, Belarus has become linked with Russia through a multitude of bilateral treaties and agreements covering virtually all areas of inter-state action. As a result, Russia's relationship with Belarus is closer than that of any other former USSR country. Ambrosio (2006), notes that the situation in Belarus is such that the external factors that have proved to promote democratization have been weakened or undermined by its relationship with Russia in general, and by the proposed Russia-Belarus union in particular (Ambrosio, 2006).

Russian leaders, including Putin, have consistently legitimized Lukashenko's rule both diplomatically and politically, not least through defending Belarus's unfair and unfree elections. In the economic realm, Russia-Belarus trade and Russian subsidies shield Belarus from any possible trade sanctions from Western Europe, thus sustaining the regime's unreformed economic system (Ambrosio, 2006).

\section{Europeanization through the prism of Belarusian and Armenian domestic actors}

Belarus' and Armenia's responsiveness towards the EU's policies has a great deal to do with the influence of domestic political elites and local powerful groups over shaping, changing or even obstructing the process of the countries approximation towards Europe. That said, "despite the increasing external competition over the post-Soviet space, domestic actors remain the key agents to account for the pattern of change in the contested neighbourhood" (Ademmer et al. 2016). This comes down to the interests, perceptions and 
preferences of powerful local actors, often called the 'gatekeeper elites' to determine how fast these countries approach Europe through the process of Europeanization (Kakachia et al., 2019, p. 4). It follows that the mechanisms which the EU uses to shape domestic actors' incentives and capacities for taking on EU rules are critical to the process of Europeanization.

Clearly, Lukashenko's authoritarian regime with its heavy dependence on Russia has been one of the core hindrances to the country's full-hearted Europeanization. Essentially, Belarus has become an example of the reversibility of democratic transformations. The rule of Alexander Lukashenko in Belarus has created one of the most resilient authoritarian regimes in post-communist Europe. Belarus has been characterized by 'Soviet nostalgia' rather than European aspirations. Politically, Belarus shows more similarities with the republics of post-Soviet Central Asia than with its neighbors in Europe. Since the collapse of the Soviet Union Belarus has gone from being a new and fragile democracy to a pariah state, largely regarded as "the last dictatorship in Europe" (Rudling, 2008). In effect, authoritarianism in Belarus appears to last longer than expected, thus obstructing the country's rapprochement with the EU.

As for Armenia, it is noteworthy that Armenian authoritarian incumbents and oligarchic clans have long obstructed country's Europeanization. Even though after the 2018 "Velvet Revolution," oligarchs are no longer overrepresented in Armenian government, it is premature to contend that there are no oligarchs in Armenia, given that their huge influence over the Armenian economy may well translate into political power. Well acknowledging the depth of oligarchic influence across the country the Armenian government would avoid resorting to a shock therapy. Instead, it has adopted a gradualist approach to deoligarchization.

Besides, there are two major factors that merit emphasis in terms of assessing the domestic actors' role in Europeanization in the two countries. The first factor/concern is the centralization of power in both countries to the point, where checks and balances become impracticable.

As noted earlier, the Belarusian regime led by Europe's 'last dictator', Alexander Lukashenko, has been characterized by centralization and personalization of power, along with its strong tendency to suppress dissent, coerce opposition and civil society. As a result, the administration of President Lukashenko finds itself in a state of confrontation with 'the West', primarily due to its non-espousal of these standards - at least as perceived by the country's critics (Rontoyanni and Korosteleva, 2005). 
More specifically, the freedom of assembly and expression have been severely limited, with the government controlling the media narrative on politically sensitive issues. The opposition has been weak and fragmented, with opposition actors maintained in a 'ghetto', tightly managed by the ruling authorities. Moreover, it has not been uncommon for opposition activists to get harassed, threatened and arrested (Kolarzik and Terzyan, 2020).

As for the Armenian leadership, it is necessary to note that the acting Prime Minister Nikol Pashinyan capitalized on his huge popularity and through snap elections significantly consolidated his power. He would be largely treated as a "saviour" capable of turning Armenia's plight around and putting it on the path to prosperity and democracy. Meanwhile, the huge power in the hands of a charismatic leader is fraught with power abuses in the absence of powerful opposition. There has been a strong tendency in Pashinyan's discourse to style its regime as "people's government" that introduces a new form hyper-democratic interaction between state and society. More specifically, Pashinyan's discourse regarding the "people's government" has reached a point where there seems to be a blurred line between state and society. Given huge public support for Pashinyan's government manifested in its landslide parliamentary victory in December 2018, Pashinyan and his proxies even contend that any step against their government is a step against the Armenian people, as they represent the "people's government" (Factor, 2019). Pashinyan suggests that he embodies the will of the people and that Parliament's legitimacy is based on that will: "In Armenia, there is no coalition government. In Armenia, there is no parliamentary majority. In Armenia, the ultimate power directly belongs to the people and the people carry out direct rule. This is the key meaning of the revolution that took place in Armenia" (Armenian Weekly, 2018).

Meanwhile, the heavy war defeat that Armenian endured in November 2020, devastatingly affected Pashinyan's legitimacy and undermined his reputation. Among others, it shows that sustainability of reforms in Armenia considerably depends on its shift from charismatic leadership to functional democratic institutions, that translate leaders' visions into policies sustained by appropriate structures, rules, and procedures.

It is noteworthy that the former Armenian president Serzh Sargsyan, had altered the constitution to allow greater powers for the office of the Prime Minister. Pashinyan was one of the most vocal critics of that change. No wonder Pashinyan-led "Velvet Revolution" prevented Sargsyan from wielding that power, which Pashinyan himself inherited. Yet, 
during his press conference, when journalists asked whether he had any intention of trimming some elements of that power, Pashinyan's answer was that the revolution had already taken care of that issue (Mirror-Spectator, 2019). Thus, consistent with the narrative of "people's government," he would argue that he embodies the will of the people and that Parliament's legitimacy is based on that will (Pashinyan, 2018).

The second major factor in terms of increasing domestic actors' responsiveness towards the European policies is related to the advancement of a vibrant and consolidated civil society in both countries.

A vibrant civil society has long been thought to be a crucial instrument for political change in countries in transition and a key component of a democratic society.

In both countries civil society organizations have been characterized by their organizational weakness, and marginality in terms of their social base, financial assets and influence over policy making.

Controlling the mass media and civil society has been crucial for Europe's 'last dictator' Alexander Lukashenko's rule. As a result, freedom of association has been extremely limited in Belarus, where the registration of groups remains entirely arbitrary, while the foreign funding to NGOs is treated as interference in the country's domestic affairs. Only a few human rights groups continue to operate, amid huge harassment by the government. Alarmingly, in 2018, the Criminal Code of Belarus introduced the prospect of large fines for unregistered or liquidated organizations, thus aiming to curb their activism (Freedom House, 2019).

Moreover, the lack of a vibrant civil society has led to a situation where Belarusians have huge misconceptions about civil society organizations and do not tend to use the available resources within civil society and human rights organizations to defend their rights. Public opinion surveys show that half of those surveyed (50.6\%) assesses the human rights situation in Belarus as stable and unchanging. One-third of respondents (29.9\%) believe that the overall human rights situation has deteriorated over the past few years, and only 7.0\% believe there have been positive developments in this area. Respondents believe that the government is responsible for respecting human rights but is de facto incapable of providing sufficient guarantees for everyone and, when human rights are violated, is not able to provide the necessary redress. At the same time, around one-half $(51.5 \%)$ of respondents agree that it is imperative to defend one's own rights, even if it contradicts the interests of the state (Freedom House, 2016). 
The situation in Belarus turned upside down in the wake of 2020 presidential elections, that unleashed a huge wave of civic activism: hundreds of thousands of Belarusians raising their voices and taking to the streets.

The anti-government protests following the 2020 presidential elections show that the Belarusian opposition and civil society have the potential to challenge the status quo meticulously preserved by Lukashenko.

Nevertheless, it would be misleading to treat the successful actions by protesters or even civil society representatives per se as s shift in a robust or "emerging" civil society. The question remains as to if protests are organized by well-established and institutionalized organizations, or do groups emerge spontaneously out of the protests themselves? (Terzyan, 2020).

By contrast, the Armenian civil society organizations enjoy considerable freedom and face less harassment by the government. While civil society played a critical role in the "Velvet Revolution," the absence of an umbrella organization or clearly reform-oriented movement in Armenia, seems to leave the fate of the societal coalition that brought Nikol Pashinyan to power uncertain. Not surprisingly, the societal coalition started to break into pieces as Armenia endured tremendous setbacks in the war against Azerbaijan in November 2020. Overall, the demonstrations leading the revolution showed the "Velvet Revolution was a one-time fairy tale, rather than a feature of a vibrant civil society. Meanwhile, civil society organizations and activists need to move beyond the victory in the street and pursue victory in town halls and elections, with the growing realization that the "Velvet Revolution" now needs to be in people's minds and behavior rather than in downtown Yerevan .

Studies show that despite the growing number of civil society organisations (there are more than 4,000 registered civil society organisations, mainly non-governmental organisations), the absolute majority of them are inactive with little to no potential to represent certain interest groups (Gevorgyan, 2017). Not surprisingly, the EU has placed a pronounced emphasis on establishing a bilateral EU-Armenia civil society organization platform as an integral part of the bilateral relations. The aim is to empower CSOs increase their involvement in promotion and oversight of reforms, leading to the successful implementation of the CEPA (Action Document for CEPA Reform Facility, 2019, p. 8).

Arguably, the Russian oversize influence over Belarus and Armenia has been one of the core challenges to a vibrant civil society advancement in both countries. Of all the Eastern 
Partnership countries, Armenia and Belarus is by far the most vulnerable to Russian influence. This reflects its structural dependence on Russia in the economic, energy, security, geopolitical, as well as socio-cultural spheres, particularly in case of Belarus.

Belarus displays a series of characteristics that allow Russia to have a strong impact on civil society. These include a weak national identity, issues around language, the prevalence of Russian information in the media, exposure to Russian information warfare, as well as the presence in Belarus of Russian government-organized NGOs (GONGOs) and the Russian Orthodox Church (Terzyan, 2020).

Notably, within its strategy of promoting Eurasian integration within the Eurasian Economic Union and beyond, Russian propaganda would frequently target Armenian NGOs by framing those which are Western-funded ones as threats to Armenian-Russian relations. Such claims would be followed by the calls for 'neutralizing' them through information campaigns and other methods, including through the legislature. Not surprisingly, the 2017 amendments to existing NGO legislation in Armenia, with imposed restrictions on their activities, would be largely viewed as a direct result of the mounting pressure emanating from Russia (Roberts and Ziemer, 2018).

The question remains as to if the EU's emphasis on civil society advancement can boost its actorness on the one hand and increase the demand for Europeanization on the other in the two countries.

Studies show that the path to a vibrant and consolidated civil society has two main dimensions. The first dimension boils down to the changes in the nature of civil society relations with the state and society and its potential and ability to induce reform, or what is often referred to as "change on the outside" (Shapovalova and Burlyuk, 2018). This has much to do with increasing their impact on public policy and practice, not least through engaging more with their constituencies and improving their interaction with public institutions and actors. It has not been uncommon for post-Soviet societies to treat civic associations as threat to the power and stability of the state together with the conviction that the state bears the responsibility for the wellbeing of the society.

Moreover, the CSOs' tendency to prioritize relations with Western donors over engagement with citizens would result in their treatment as donor-driven, rather than community-oriented organizations. Meanwhile, greater engagement and effective communication with various social groups is critical to breaking down the public misconceptions about CSOs and their activities (Terzyan, 2020). 
Thus, the "change on the outside" is instrumental in dissolving the apathy of the wider public leading to their shift from spectators to actors.

A major impediment to civil society in both countries is prevailing post-Soviet "informality" in the form of behavioral practices, such as considerable tolerance towards informal governance, the use of informal networks and connections in exchanges of favors, phone justice, corruption, etc. The latter has long condemned both countries to a vicious circle of underdevelopment and bad governance. Even though it would be an oversimplification to contend that graft is a way of life it takes a long time for deep rooted behavioral practices to change. Therefore, both governments, as well as CSOs have a crucial role in eradicating the informality and culture of corruption in both societies, not least through promoting liberal values and good governance practices.

The second critical dimension is "change on the inside", related to the nature of civil society per se: such as the way it is organized and operates (Shapovalova and Burlyuk, 2018). This in turn has a great deal to do with the development of adequate institutional and professional capacity in civil society organizations and networks as a vital tool for influencing policy making. The institutional development at the organizational level includes building organizational capacities for governance, decision-making, and conflict management, as well as clarifying organizational identity, values, and strategy of impact. The latter is of crucial relevance as a lot of CSOs in both countries were established in response to certain needs or funding priorities with no predefined mission, strategic plans, and organization structure. That said, they were doomed to failure in terms of addressing the specific needs of their constituencies.

Overall, these changes and reforms are vital to the advancement of a vibrant civil society that can become an agent of democracy and Europeanization in both countries.

\section{Challenges and opportunities in sectorial partnership}

The EU has been consistent in terms of seeking deep and comprehensive partnership with Belarus and Armenia beyond the Association Agreements. A question arises as to whether and to what extent the countries have been responsive to the EU demands for reforms.

The EU has tended to place a strong emphasis on the democratization of Belarus, as a precondition for deepening the bilateral partnership. The European Commission's Strategy Paper of 12 May 2004 specifically states: “The EU's long-term goal for Belarus is to be a 
democratic, stable, reliable, and increasingly prosperous partner with which the enlarged EU will share not only common borders, but also a common agenda driven by shared values. 2 Through the ENP, the EU will reinforce its lasting commitments to supporting democratic development in Belarus" (Van Elsuwege, 2010).

The European Parliament has laid down five concrete conditions to be fulfilled: (1) Belarus needs to remain a country without political prisoners; (2) Freedom of expression for the media needs to be guaranteed; (3) The authorities need to cooperate with the OSCE on reform of the electoral law; (4) The conditions for the work of non-governmental organizations (NGOs) need to be improved; (5) The freedom of assembly and political association has to be guaranteed (Van Elsuwege, 2010).

Meanwhile, as noted earlier, Belarus has significantly failed to meet these demands. As a result, Belarus is the only country in the EU's neighborhood without a proper overarching agreement. Nevertheless, the EU has been enhancing cooperation with Belarus through bilateral sectoral dialogues on economic and financial issues, customs, energy, and environment and on trade. As Belarus happens to be a pivotal energy transit country for Europe, there appears to be much room for tightening the cooperation in the energy sector. Well acknowledging the limits of deepening energy partnership with Russia's 'special' partner Belarus, the EU has consistently pushed for fulfillment of its modest agenda. Through the EBRD-managed Eastern Europe Energy Efficiency and Environment Partnership, Belarus has access to $€ 10$ million for key projects in energy efficiency and environmental protection. The first project - Puhovichi Solid Waste - has helped to leverage total investments of $€ 7$ million (Europea, 2020). A new investment grant for wastewater treatment facilities in 6 cities in Belarus was also approved at the end of 2019. EU support has helped to improve energy efficiency in educational facilities for the benefit of 2,000 school and preschool children, and support to modernization has improved the living conditions of 10,000 citizens and reduced electricity bills for 10 municipalities (Europea, 2020).

Given that Armenia has no importance for the EU as an energy supplier or a transit country, the European policy has chiefly targeted the areas of sustainable energy development and resilience-related matters. The EU reports would place emphasis on the power plant closure and a new one's compliance with the latest international safety standards (Terzyan, 2019b, pp. 105-106). However, the EU has been quite active in supporting the safe operation of Medzamor nuclear power plant until its full decommissioning in 1990 with more than $€ 60$ million. Besides, in order to facilitate energy exchanges between Armenia and 
Georgia and diversification of available energy sources, it has embarked on the creation of a transmission network in Ayrum (Terzyan, 2019b, p, 106). A question arises of whether the CEPA package has the potential to enhance Armenia's energy resilience and to boost energy cooperation. Notably, the treaty on the EAEU obligates its members to carry out coordinated energy policy with regards to the development of common electricity, gas and oil markets (Treaty on the EEU 2014, art. 79, 81, 83, 84). Moreover, in 2013, the governments of Armenia and Russia signed an agreement which granted Gazprom exclusive rights for gas supply and distribution in Armenia by 2044, rendering it the $100 \%$ shareholder of the country's gas industry (Azatutyun, 2014). The deal further plunges Armenia's energy sector into the orbit of Russian state-run companies and thus militates against its Europeanization. The EU's measures strike as insufficient in addressing Armenia's energy diversification amidst Gazprom's unshakeable dominance over the country's energy sector. Thus, energy remains the most challenging and closed sector in Armenia, compounded by the Eurasian integration.

Remarkably, former Armenian president Serzh Sargsyan once candidly admitted that one of the determining factors in Armenia's decision to join the Eurasian Economic Union instead of signing the Association Agreement with the European Union was heavy energy dependence on Russia. That said, making a "civilizational choice," would condemn Armenian consumers to pay thrice more for the Russian gas (Terzyan, 2018, p. 238). To counter Gazprom's abuses, Pashinyan's government launched an investigation in Gazprom Armenia and which led to finding a series of irregularities and even to accusing it of tax evasion and corruption (Terzyan, 2019c, p. 127). In response to Gazprom increased gas prices for Armenia in 2019, thus showing the consequences of fighting against its monopoly (Terzyan, 2019c, p. 127). That said, by using Gazprom's “energy weapon” and increasing gas prices for Armenia, the Kremlin reportedly strived to thwart the repetition of Ukrainianstyle gas reforms in Armenia.

The similar set of problems applies to the partnership in the field of transport and connectivity. While the EU consistently strives to foster cooperation in the fields of transport connectivity and telecommunications with the view to extending the core TransEuropean Transport Network (TEN-T) to the Eastern partners, Armenia remains bound by the Eurasian constraints. More specifically, article 86 of the treaty on the EAEU stipulates that "the Union carries out coordinated transport policy, with the view to ensure economic 
development, step by step and consistent formation of common transport area based on the principles of competition, openness, security, reliability, availability and sustainability" (Treaty on the EEU 2014, art. 86). Clearly, the strong emphasis on common transport policy within the EAEU may well prevent Armenia from advancing profoundly towards the European realm of transport and connectivity.

Remarkably, the political tensions between the EU and Belarus have not appeared to adversely affect trade partnership. Namely, in 2011, when political tensions reached their peak mutual trade turnover amounted to $\$ 24.4$ billion. Belarus's exports to the EU increased by about 30 percent in 2018 and nearly reached the record-high level registered in 2012 (Preiherman, 2020). As a result, EU is the second trade partner for Belarus after Russia and accounts for above one quarter of its total trade (Synowiec, 2016).

Besides, the EU has been supporting economic reforms in Belarus, aimed at improving the business climate and fostering economic growth. The EU has assisted 4,500 Belarusian companies with funding, training, and export support to new markets through the EU4Business initiative: 5,700 new jobs were created helping small and medium size enterprises grow (Europea, 2020). Notably, the EU has been encouraging Belarus to accede to the WTO as soon as possible as it would contribute to the modernization of the country's economy, would improve public governance, and diversify its exports (Synowiec, 2016).

One of the intriguing questions regarding the CEPA is whether and to what extent its provisions can contribute to Armenia's economic development given a limited EU conditionality.

There has been a tendency for Pashinyan's discourse to revolve around "economic revolution." The government plan promised a significant decrease of the severe poverty in Armenia and a significant decrease in unemployment by 2023 (Eurasianet, 2019). Yet, there remain considerable obstacles to "economic revolution," emanating particularly from Armenia's steady integration into the Russian-dominated Eurasian Economic Union. It is worth to note that articles 4 and 8 of the treaty on the EAEU obligate member states to create a common market of goods, labour and services and have their economic policies complied with the goals and principles of the EAEU (Treaty on the EEU 2014, art. 4, 5). According to article 25, there is a common regime of trade of goods with third parties (Treaty on the EEU 2014, art. 25). All these stipulations limit Armenia's ability to boost trade and broader economic partnership with the EU. The EU has been exercising power by externalizing its internal market-related policies and regulations and thus acting as a Market Power Europe 
(Damro, 2010). Meanwhile, Armenian integration into a competing rival project significantly prevents the EU rules and norms from travelling across the country.

Unsurprisingly, the EU officials from the EEAS were quick to foresee constraints in the EU-Armenia economic cooperation, noting that mostly non-preferential access to the EU market amid deepening Eurasian economic integration render a number of EU's economic tools impracticable vis-à-vis Armenia ${ }^{1}$.

It is noteworthy, that whilst taking full account of Armenia's obligations as a member of the EU, the CEPA contains commitments in several policy areas aiming to improve conditions for bilateral EU-Armenia trade. Boosting trade partnership is inherently related to tackling a series of differences between the EU and Armenia, which exist regarding technical regulations, metrology, standardisation, market surveillance, accreditation and/or conformity assessment procedures (Action Document for CEPA Reform Facility, 2019, p. 7).

Clearly, the Armenian economy would tremendously benefit from its full exposure to the EU's "market power," as the issues of comprehensive economic partnership get addressed trilaterally between the EU, Armenia and the EAEU.

Within the measures designed to stimulate economic development and enhance stability, the reviewed ENP places marked emphasis particularly on youth employment and employability (European Commission, 2015). Improving employability and promoting knowledge-based economic growth envisages reinforcing struggle against brain-drain and even promoting incentive schemes for well-educated people to return to their home country. Meanwhile, irregular migration and large-scale brain-drain remains one of the most formidable challenges facing Armenia. Clearly, the economic disarray has inflicted severe hardships on the Armenian population, forcing them to flee the country (Terzyan, 2019, p. 131). Russia remains one of the favourite and most accessible destinations for Armenian migrants and according to various estimates is home to over two million Armenians. More specifically, seasonal labour migration to particularly Russia has constituted a crucial survival strategy for many Armenian households to this day. According to the official data, annually, more than 200,000 Armenians go to Russia for seasonal employment (Terzyan, 2019b, p. 105). Given that Armenia's membership in the EAEU eliminates visa-relatedbarriers and thus facilitates the free movement of Armenian labour force, massive outflow

${ }^{1}$ Interviews with EEAS - related officials from September 2015 to February 2016. 
of Armenian population to Russia seems bound to continue. While Armenia's most influential partner, Russia, does not oppose to irregular migration, the EU's policy tools would have a limited role in addressing the above-mentioned alarming trends. Nevertheless, the CEPA chapters related to equal opportunities, social policy and employment include substantial EU acquis on safety at work, equal treatment, gender and racial equality, antidiscrimination, and essential labour market regulations (CEPA, 2017).

Thus, Armenia's consistent compliance with these provisions would allow for the EU's remedial measures to trickle down to country's sustainable development.

Delcour (2018) notes that Armenia's "Velvet Revolution" took place at a time when the EU seemed prepared to support democratisation and political reform more actively (Delcour, 2018, p. 19). More specifically, the launch of a visa dialogue with Armenia may give a strong impetus to reforms in the country owing to the increased conditionality as part of the Visa Liberalisation Action Plan (Delcour, 2018, p. 19).

In recognition of the post-revolution Armenian government's reform efforts, the EU almost doubled its support to Armenia in 2019 (EEAS, 2019a). The EU has emphasized the necessity of reforms that would lead to the rule of law, fight against corruption and respect for human rights, along with independent and accountable judicial system (EEAS, 2019a). Overall, the EU allocated an additional $€ 25$ million in the context of its 2019 Annual Action Plan of assistance for Armenia (EEAS, 2019b).

Admittedly, rampant corruption prevalent in Belarus and Armenia has significantly hindered their advancement towards the EU, by condemning the countries to a vicious circle of underdevelopment, poor governance, and inability to implement reforms.

Belarus is the 66 least corrupt nation out of 180 countries, according to the 2019 Corruption Perceptions Index reported by Transparency International (Trading Economics, 2020). Corruption is present at all government levels in Belarus; customs, public procurement, and construction are particularly vulnerable sectors (Belarus Corruption Report, 2020).

The EU has been supporting anti- corruption efforts in Belarus through Good governance and fight against corruption in Belarus (PGG-Belarus). The latter is part of the overall CoE/EU Partnership for Good Governance (PGG) Programme "Fight against corruption and fostering good governance/ Fight against money-laundering" assistance facility to the Eastern Partnership countries. It is one of the National Components primarily focused on strengthening efforts aimed at preventing and fighting corruption. The overall 
objective of the PGG-BE project is to contribute to democracy and the rule of law through strengthening of good governance and anti-corruption mechanisms. Accordingly, the PGG$\mathrm{BE}$ aims at strengthening institutional capacities to prevent and counter corruption in Belarus, in accordance with applicable European standards (COE, 2020). Despite the EU's efforts, Lukashenko's authoritarian rule seems detrimental to defeating corruption. Meanwhile rampant corruption and weak rule of law would considerably undermine the overall progress Belarus has made with other reforms.

Notably, rampant corruption has been one of the biggest hindrances to Armenia's democratic development and one the root causes of the "Velvet Revolution."

Unsurprisingly, the new government targeted the fight against corruption as a top priority. Namely, the anti-corruption efforts prompted Pashinyan's government to criminalise illicit enrichment (Calliher, 2019). Pashinyan has attached particular importance to judicial corruption. Following the controversial release of President Robert Kocharyan, Pashinyan contended that the judiciary is a remnant of the former corrupt system that would cook up conspiracies against the Armenian people (Asbarez, 2019). As a result, he called for a mandatory "vetting" of all judges in all the courts in the country because of their ties to the previous regime (Asbarez, 2019). Such statements are testaments to the difficulty of eliminating the deep-rooted authoritarian legacy, especially when it comes to a fight against judiciary corruption. Nevertheless, because of the Armenian government's anti-corruption measures, Armenia has considerably improved its position in an annual survey of corruption perceptions around the world conducted by Transparency International. It ranked 77th out of 180 countries evaluated in the watchdog's 2019 Corruption Perceptions Index (Azatutyun, 2020). The EU's positive input cannot be underestimated. Following the launch of an EUArmenia dialogue on judicial reform in September 2018, the EU has expressed its willingness to provide further support for comprehensive judicial reform based on a justice reform strategy (EEAS, 2019b).

Essentially, in both countries the political elites' robust commitment to curbing systemic corruption is vital to the success of anti-corruption policies. As the Romanian experience shows, the political will to defeat corruption may well offset the absence of a tradition of the rule of law and democracy. More specifically, the European Union pressure, along with the electoral pressure and the political will of the domestic political elite combined to ensure the establishment of the rule of law and defeating corruption in the Romanian 
judiciary between 1997 and 2006 (Ritsei, 2010). Clearly, there is no magic bullet for eliminating corruption and much depends on public support for anti-corruption policies that should also increase domestic actors' responsiveness towards the EU's policies.

\section{Conclusion}

This paper contributes to the existing literature and ongoing debate regarding the anatomy of the Europeanization processes in the EU's Eastern neighbourhood amid constraining conditions emanating from "competing governance provider" Russia. Based on the previous discussion, there are three main concluding observations to make regarding the EU approximation trajectories of Belarus and Armenia.

Firstly, and in terms of the dynamics of Europeanization from the perspective of domestic actors (political elites, powerful local groups), the their' interests, perceptions and preferences significantly influence the ways in which EU policies are received and implemented both in Belarus and in Armenia. The sustainability of reforms in both countries considerably depends on their shift from authoritarian or semi-authoritarian regimes to functional democratic institutions, sustained by appropriate structures, rules, and procedures. Overall, to improve domestic actors' responsiveness towards the EU policies, it is essential to implement democratic reforms and achieve a reasonable balance between executive and legislative powers. All these have much to do with the advancement of vibrant civil societies, capable of holding domestic incumbents accountable.

Secondly, in terms of sectorial partnership with the EU, the two countries' obligations as members of the Eurasian Economic Union adversely affect their ability to boost economic partnership with the EU, as well as to deepen cooperation in the fields of energy, transport and connectivity. Against this backdrop the political tensions between the EU and Belarus have not appeared to adversely affect the trade partnership: the EU is the second trade partner for Belarus after Russia and accounts for above one quarter of its total trade. Besides, the EU has been supporting economic reforms in Belarus, aimed at improving the business climate and fostering economic growth. Similarly, despite a series of challenges and constraints, stemming chiefly from Armenia's Eurasian integration, the CEPA opens considerable opportunities for further Europeanization of country's legal and political systems. Its successful implementation significantly depends on Armenian leadership's ability at skilfully balancing Eurasian integration with further compliance with the EU policies. To further the processes of Europeanization, both countries need to step up their anti-corruption efforts, especially at defeating judicial corruption. 
Thirdly, in terms of the interactions with "competing governance provider," of all the Eastern Partnership countries, Armenia and Belarus remain the most vulnerable to Russian influence. Despite the EU's intensifying engagement with the two countries, they have proved unwilling or unable to diminish their overwhelming dependence on Russia and step down the path of the other EaP partners.

Further research is essential to explore the dynamics of the Europeanization in Belarus and Armenia, focusing specifically on evolving preferences, perceptions and interests of domestic actors and their responsiveness towards the EU's policies.

\section{References}

Aberg, J. H. and Terzyan, A. (2018). Structure or agency? Explaining Armenia's foreign policy evolution. Eastern Journal of European Studies, 9(1), pp. 151-172.

Action Document for CEPA Reform Facility (2019). https://ec.europa.eu/neighbourhood-

enlargement/sites/near/files/annexes/c_2019_8734_f1_annex_en_v1_p1_1054438.pdf (4.04.2020).

Ademmer, E. (2015). Interdependence and EU-demanded policy change in a shared neighbourhood. Journal of European Public Policy, 22(5), pp. 671-689.

Ambrosio, T. (2006). The Political Success of Russia-Belarus Relations: Insulating Minsk from a Color Revolution. Demokratizatsiya, 14(3), pp. 407-434.

Ambrosio, T. (2016). Authoritarian backlash: Russian resistance to democratization in the former Soviet Union. Routledge.

Armenian Weekly (2018). Highlights from Pashinyan's first 100 days speech, https://armenianweekly.com/2018/08/18/highlights-of-pashinyans-first-100-days-speech/ (19.01.2020).

Asbarez (2019). Pashinyan calls for overhaul of judiciary, http://asbarez.com/180731/pashinyan-calls-for-overhaul-of-judiciary/ (11.01.2020).

Azatutyun (2014). Gazprom completes Armenian gas network takeover, https://www.azatutyun.am/a/25233311.html (11.01.2020).

Azatutyun (2020). Armenia advances in global corruption rankings, https://www.azatutyun.am/a/30393305.html (02.04.2020).

Belarus Corruption Report (2020), https://www.ganintegrity.com/portal/countryprofiles/belarus/

Calliher, C. (2019). For Armenia's Pashinyan Poroshenko's presidency should serve as a cautionary, Atlantic Council, https://www.atlanticcouncil.org/blogs/new-atlanticist/forarmenia-s-pashinyan-poroshenko-s-presidency-should-serve-as-a-cautionary-tale/ (11.01.2020).

CEPA (2017). Comprehensive and Enhanced Partnership Agreement between the European Union and the European Atomic Energy Community and their Member States, of 
the one part, and the Republic of Armenia, of the other part, https://cdn3eeas.fpfis.tech.ec.europa.eu/cdn/farfuture/S17QI437S_ttyiGoqFm6o6ecE564mEUsiCPcYb ga97s/mtime:1514986780/sites/eeas/files/eu-

armenia_comprehensive_and_enhanced_partnership_agreement_cepa.pdf (11.01.2020).

COE (2020). Good governance and fight against corruption in Belarus (PGG-Belarus), https://www.coe.int/en/web/corruption/completed-projects/pgg-belarus (10.10.2020).

Damro, C. (2010). Market Power Europe: EU externalisation of market-related policies. MERCURY Working Paper, http://www.europa.ed.ac.uk/_data/assets/pdf_file/0004/206887/Mercury-Paper-5.pdf (11.01.2020).

Delcour, L. (2018). Political changes in Armenia: a litmus test for the European Union. Caucasus Analytical Digest, No. 104, pp. 17-20.

Delcour, L. and Kostanyan, H. (2014). Towards a fragmented neighbourhood: Policies of the EU and Russia and their consequences for the area that lies in between. CEPS Essays, (17), pp. 1-10.

Delcour, L. and Wolczuk, K. (2015). The EU's unexpected 'ideal neighbour'? The perplexing case of Armenia's Europeanisation. Journal of European Integration, 37(4), pp. 491-507.

Delcour, L. and Wolczuk, K. (2017). Between the Eastern partnership and the Eurasian economic union: Competing region-building projects in the 'common neighbourhood'. Theorizing the European neighbourhood policy, pp. 187-206.

EEAS (2019a). Remarks by President Donald Tusk after his meeting with Prime Minister of Armenia Nikol Pashinyan, https://eeas.europa.eu/delegations/armenia/65223/node/65223_my (19.01.2020).

EEAS (2019b). Joint press statement following the second Partnership Council meeting between the EU and Armenia, https://eeas.europa.eu/headquarters/headquartershomepage/64088/joint-press-statement-following-second-partnership-council-meetingbetween-eu-and-armenia_en (19.01.2020).

Eurasianet (2019). Armenia adopts plan for "economic revolution," https://eurasianet.org/armenia-adopts-plan-for-economic-revolution (19.01.2020).

Europea (2020), https://www.consilium.europa.eu/media/44399/685-annex-5-cbelarus-factsheet.pdf(10.10.2020).

European Commission (2015). European Commission and EEAS, Review of the European Neighbourhood Policy, http://eeas.europa.eu/archives/docs/enp/documents/2015/151118_jointcommunication_review-of-the-enp_en.pdf (10.01.2020).

Factor (2019). The actions of sabotage against people's government mean actions of

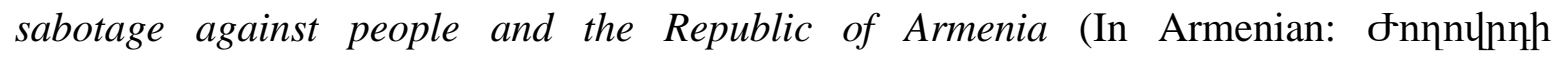

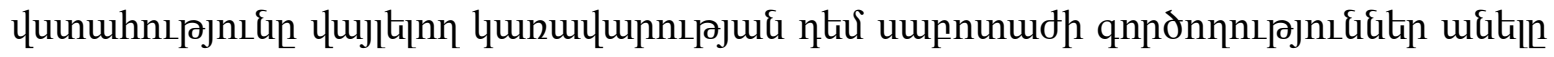

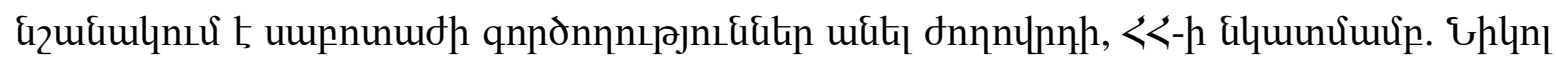
Фu2hॄjui), https://factor.am/55233.html (18.01.2020).

Frear, M. (2019). Belarus under Lukashenka: Adaptive Authoritarianism. Routledge 
Freedom House (2016). Belarus: Public Opinion About Human Rights And Advocacy, https://freedomhouse.org/sites/default/files/2020-

02/FH_Belarus_HR_Sociology_Report_ENG_PRINT.pdf (10.11.2020).

Freedom House: Belarus (2019), https://freedomhouse.org/country/belarus/freedomworld/2019 (10.11.2020).

Gevorgyan, V. (2017). The Next Step in the development of Armenian civil society. Open Society Foundation Armenia, http://www.osf.am/wp-content/uploads/2017/11/TheNext-Step-in-the-Development-of-Armenian-Civil-Society-paper.pdf (10.01.2020).

Grabbe, H. (2006). The EU's transformative power. Europeanization through conditionality in Central and Eastern Europe, New York: Palgrave Macmillan.

Hahn, J. (2015). The 2015 ENP Review: How different is the policy now? Centre for European Policy Studies

Haukkala, H. (2018). 'Crowdfunded diplomacy'? The EU's role in the triangular diplomacy over the Ukraine crisis. In Triangular Diplomacy among the United States, the European Union, and the Russian Federation, pp. 77-94.

IRI (2019). New Armenia poll: high public confidence in government; enduring economic concerns, https://www.iri.org/resource/new-armenia-poll-high-public-confidencegovernment-enduring-economic-concerns (04.04.2020).

Kakachia, K., Lebanidze, B. and Dubovyk, V. (2019). Defying marginality: explaining Ukraine's and Georgia's drive towards Europe. Journal of Contemporary European Studies, 27(4), pp. 1-12.

Kolarzik and Terzyan (2020). The State of Human Rights and Political Freedoms in Belarus: Was the Crisis Inevitable? Post-Soviet Politics Research Papers, Number 4, pp. 215 .

Korosteleva, E. A. (2016). Eastern partnership and the Eurasian Union: bringing 'the political'back in the Eastern region. European Politics and Society, 17(1), pp. 67-81.

Kostanyan, H. (2016). The European Neighbourhood Policy reviewed: Shifting from value-driven to classical foreign policy, in: Hugh, A. (Ed.), Institutionally blind? International organisations and human rights abuses in the former Soviet Union, pp.17 -20, https://biblio.ugent.be/publication/8514016/file/8514017.pdf (16.02.2020).

Kostanyan, H. and Giragosian, R. (2017). EU-Armenian relations: Charting a fresh $\begin{array}{llll}\text { course. } & \text { REPS } & \text { Report } & \text { No. }\end{array}$ https://www.ceps.eu/system/files/HKandRG_EU_Armenia.pdf (19.01.2020).

Lavenex, S. and Schimmelfennig, F. (2009). EU rules beyond EU borders: theorizing external governance in European politics. Journal of European public policy, 16(6), pp. 791812.

Lavenex, S. and Schimmelfennig, F. (Eds.). (2013). EU external governance: projecting EU rules beyond membership. Routledge.

Mirror-Spectator (2019). A Year after the Velvet Revolution, https://mirrorspectator.com/2019/05/16/a-year-after-the-velvet-revolution/ (19.01.2020). 
Pashinyan (2018a). Prime Minister Nikol Pashinyan's speech at rally dedicated to 100 days in office, https://www.primeminister.am/en/statements-andmessages/item/2018/08/17/Nikol-Pashinyan-100-day-rally/ (17.01.2020).

Pashinyan (2018b). Address by acting Prime Minister Nikol Pashinyan to National Assembly, $\quad$ https://www.primeminister.am/en/statements-andmessages/item/2018/10/24/Nikol-Pashinyan-Speech-National-Assembly/ (19.01.2020).

Petrov, R., Van der Loo, G. and Van Elsuwege, P. (2015). The EU-Ukraine Association Agreement: a new legal instrument of integration without membership? Kyiv-Mohyla Law and Politics Journal 1, pp. 1-19.

Preiherman (2020). Belarus and the EU: Where Could Another Rapprochement Lead?, https://jamestown.org/program/belarus-and-the-eu-where-could-another-rapprochementlead/ (10.10.2020).

Prodi (2002), A Wider Europe - A Proximity policy as the key to stability, https://ec.europa.eu/commission/presscorner/detail/en/SPEECH_02_619 (14.01.2020).

Racoviţă, M. (2011). Europeanization and effective democracy in Romania and Bulgaria. Romanian Journal of Political Sciences, (01), pp. 28-49.

Ristei, M. (2010), The politics of corruption: Political will and the rule of law in postcommunist Romania. Journal of Communist Studies and Transition Politics, 26(3), pp. 341362.

Roberts, S., \& Ziemer, U. (2018). Explaining the pattern of Russian authoritarian diffusion in Armenia. East European Politics, 34(2), pp. 152-172.

Rontoyanni, C. and Korosteleva, E. (2005). Belarus: An Authoritarian Exception from the Model of Post-Communist Democratic Transition? In Socializing Democratic Norms (pp. 209-231). Palgrave Macmillan, London.

Rudling, P. A. (2008). Belarus in the Lukashenka era: National identity and relations with Russia. In Europe's Last Frontier? (pp. 55-77). Palgrave Macmillan, New York.

Schimmelfennig, F. and Sedelmeier, U. (2004). Governance by conditionality: EU rule transfer to the candidate countries of Central and Eastern Europe. Journal of European public policy, 11(4), pp. 661-679.

Shapovalova, N. and Burlyuk, O. (2018). Civil society and change in Ukraine PostEuromaidan: An Introduction. In Civil society in post-Euromaidan Ukraine: from revolution to consolidation, Vol. 193, pp. 11-38.

Synowiec (2016). The EU Is Encouraging Belarus to Join the World Trade Organisation, https://emerging-europe.com/voices/the-eu-is-encouraging-belarus-to-join-the-world-tradeorganisation/ (10.10.2020).

Terzyan (2020). The State of Civil Society in Belarus and Armenia: Challenges and Opportunities. Modern Diplomacy, https://moderndiplomacy.eu/2020/12/03/the-state-ofcivil-society-in-belarus-and-armenia-challenges-and-opportunities/ (4.12. 2020).

Terzyan, A. (2017). The EU vs. Russia in the foreign policy discourse of Armenia: the fragility of normative power or the power of Russian coercion? Eastern Journal of European Studies, 8(2), pp. 185-203.

Terzyan, A. (2018). The anatomy of Russia's grip on Armenia: bound to persist? CES Working Papers, 10(2), pp. 234-250. 
Terzyan, A. (2019a). The Aftermath of the "Velvet Revolution": Armenia between domestic change and foreign policy continuity. Eastern European Journal for Regional Studies (EEJRS), 5(2), pp. 24-43.

Terzyan, A. (2019b). Russian policy, Russian Armenians and Armenia: ethnic minority or political leverage? CES Working Papers, 11(2), 124-142.

Terzyan, A. (2019c). Bringing Armenia closer to Europe: Challenges to the EU-Armenia Comprehensive and Enhanced Partnership Agreement Implementation. Romanian Journal of European Affairs, 19 (2), pp. 97-110.

Trading Economics (2020). Belarus: Corruption Rank, https://tradingeconomics.com/belarus/corruption-rank (10.10.2020).

Treaty on the Eurasian Economic Union (2014). https://www.wto.org/english/thewto_e/acc_e/kaz_e/WTACCKAZ85_LEG_1.pdf (10.01.2020).

Vachudova, M. A. (2005). Europe undivided. Democracy, leverage, and integration after communism, Oxford, New York: Oxford University Press.

Van der Loo, G., Van Elsuwege, P. and Petrov, R. (2014). The EU-Ukraine Association Agreement: assessment of an innovative legal instrument. EUI Department of Law Research Paper, https://papers.ssrn.com/sol3/papers.cfm?abstract_id=2464681 (01.02.2020).

Van Elsuwege, P. (2010). The European Union and the Belarus dilemma: between conditionality and constructive engagement. Proceedings of the Institute for European Studies, pp. 7-20. 